\title{
Taurine-magnesium Coordination Compound Attenuates Hypoxia/Reoxygenation Induced Ion Channel Dysfunction in Rat Ventricular Myocytes
}

\author{
Authors \\ L. Zhao, J.-S. Lou, Y. Kang \\ Affiliation \\ Department of Pharmacology, Tianjin Medical University, Tianjin, China
}

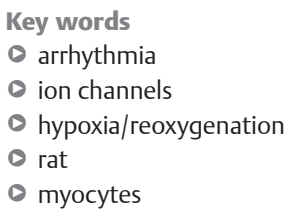

received 17.08.2012 accepted 28.01.2013

\section{Bibliography}

DOI http://dx.doi.org/

10.1055/s-0033-1334881

Published online:

March 13, 2013

Drug Res 2013;

63: 185-191

(c) Georg Thieme Verlag KG

Stuttgart · New York

ISSN 2194-9379

Correspondence

\section{J.-S. Lou}

Department of Pharmacology

Tianjin Medical University

Tianjin 300070

China

Tel.: + 86/22/2354 2686

Fax: + 86/22/2354 2524

jianshilou@163.com

\section{Abstract}

$\nabla$

Because of the known anti-arrhythmic effects of taurine-magnesium coordination compound (TMCC), the aim of the present study was to explore the electrophysiological effects of TMCC on hypoxia/reoxygenation (H/R)-induced arrhythmias in rat ventricular myocytes. Sodium current $\left(I_{\mathrm{Na}}\right)$, the L-type calcium current $\left(I_{\mathrm{Ca}, \mathrm{L}}\right)$, and the transient outward potassium current $\left(I_{\text {to }}\right)$ were evaluated using whole-cell patchclamp recordings in rat ventricular myocytes following $H / R$ injury. The $H / R$ group significantly decreased sodium currents, while L-type calcium

\section{Introduction}

\section{$\nabla$}

Taurine and magnesium are effective supplements to prevent arrhythmias and protect the myocardium [1-3]. Taurine blocks voltage-dependent L-type calcium channels, which reduces calcium channel current density and decreases pathological and drug-induced arrhythmia incidences $[4,5]$. Taurine produces a positive inotropic effect by increasing intracellular $\mathrm{Ca}^{2+}$ by activating the taurine- $\mathrm{Na}^{+}$ co-transporter and $\mathrm{Na}^{+}-\mathrm{Ca}^{2+}$ exchanger [6,7]. Magnesium, a natural calcium antagonist, inhibits $\mathrm{Ca}^{2+}$ influx through both L-type and N-type calcium channels [8]. Extracellular magnesium significantly inhibits $\mathrm{Ca}^{2+}$ influx, when extracellular calcium levels fall below physiological concentrations [9].

Our laboratory has previously shown that the combined use of taurine and magnesium was superior to either alone to treat arrhythmias induced by ischemia/reperfusion. Based on these findings, we chemically synthesized a taurine-magnesium coordination compound (TMCC, $\bullet$ Fig. 1). Over the years, TMCC has become recognized as a specific and selective antiarrhythmic agent with a low toxicity profile. Arrhythmias induced by electrical stimulation, epinephrine, aconitine, stophanthin $\mathrm{G}$, or cesium choride have all been blocked currents and transient outward potassium currents was significantly increased (all $\mathrm{p}<0.01$ ). TMCC (200 and $400 \mu \mathrm{M}$ ) prevented abnormal sodium currents induced by $\mathrm{H} / \mathrm{R}$ by inhibiting steady-state inactivation. It also counteracted abnormal L-type calcium currents induced by $\mathrm{H} / \mathrm{R}$ by inhibiting steady-state activation and facilitating steady-state inactivation. In addition, it mitigated abnormal transient outward potassium currents induced by $\mathrm{H} / \mathrm{R}$ by inhibiting steady-state activation. TMCC prevents $\mathrm{H} / \mathrm{R}$ induced arrhythmias in rat ventricular myocytes by modifying ion channel function.

by TMCC pre-treatment [10]. TMCC markedly inhibited $I_{\mathrm{Na}}$ and $I_{\mathrm{to}}$, and moderately stimulated cardiac $I_{\mathrm{Ca}, \mathrm{L}}$ in rat ventricular myocytes. These results implicate $I_{\mathrm{Na}}, I_{\mathrm{Ca}, \mathrm{L}}$, and $I_{\mathrm{to}}$ as targets of the antiarrhythmic effects of TMCC [11].

Ischemia/reperfusion ( $/ / R$ ) in vivo or hypoxia/ reoxygenation $(H / R)$ in vitro induces endothelial dysfunction, reactive oxygen species, abnormal lipid metabolism, calcium overload, and apoptosis $[12,13]$. Our laboratory has previously shown that TMCC shortens the duration of arrhythmia induced by ischemia. However, little is known about the effects of TMCC on abnormal ionic channels induced by $\mathrm{H} / \mathrm{R}$. Based on the previous results, we used $H / R$ injury to stimulate transmembrane ion channels and disrupt channel equilibrium. The efficacy of TMCC on abnormal ion channels to amiodarone, a commonly used antiarrhythmic agent, was examined.

\section{Methods \\ $\nabla$}

Animals

All experiments were carried out according to the guidelines of the local ethics committee at our institution, and our protocol was approved 


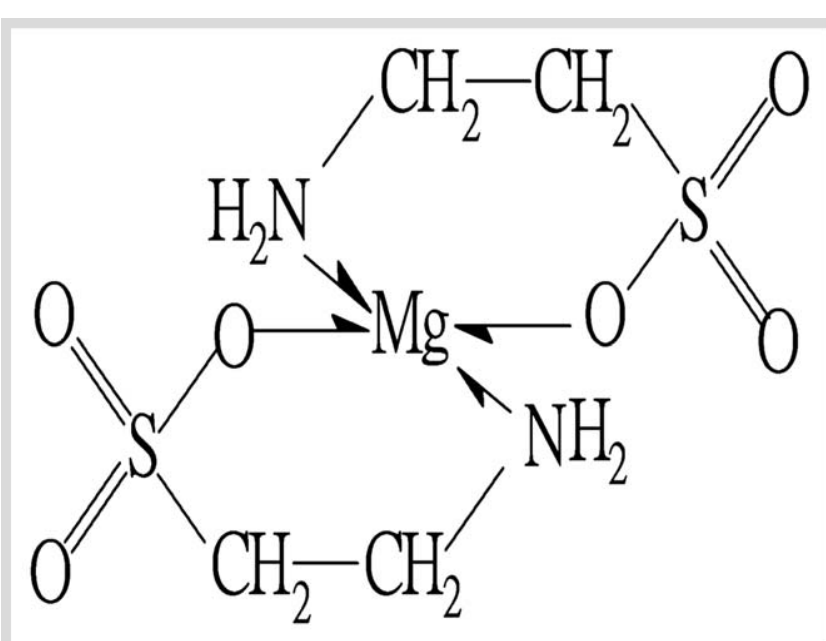

Fig. 1 Structure of taurine-magnesium coordination compound.

by the committee. Wistar rats of either sex, weighing 200-250 g (grade II, certificate no. 2008-0002) were purchased from the Experimental Animal Center of China Tianjin Medical University. Data was acquired from at least $n=6$ myocytes from 1 rat for each experiment.

\section{Drugs}

TMCC was kindly provided by the Department of Chemistry, Tianjin Medical University (batch no. 100031) and was dissolved in distilled water to prepare a stock solution $(200 \mathrm{mM})$. The stock solution was diluted with Tyrode's solution for the patch clamp studies.

\section{Solutions}

The Tyrode solution contained $126 \mathrm{mM} \mathrm{NaCl}, 5.4 \mathrm{mM} \mathrm{KCl}, 1 \mathrm{mM}$ $\mathrm{MgCl}_{2}, 1.8 \mathrm{mM} \mathrm{CaCl}_{2}, 0.33 \mathrm{mM} \mathrm{NaH} \mathrm{PO}_{4}, 10 \mathrm{mM}$ glucose, and $10 \mathrm{mM}$ HEPES, and the $\mathrm{pH}$ was adjusted to 7.4 with $\mathrm{NaOH}$. The nominally $\mathrm{Ca}^{2+}$-free Tyrode solution was prepared by removing $\mathrm{CaCl}_{2}$ from the Tyrode solution. Krebs solution was used to store cells. Krebs solution consisted of $70 \mathrm{mM}$ glutamic acid, $15 \mathrm{mM}$ taurine, $30 \mathrm{mM} \mathrm{KCl}, 10 \mathrm{mM} \mathrm{KH}_{2} \mathrm{PO}_{4}, 0.5 \mathrm{mM} \mathrm{MgCl}_{2}, 0.5 \mathrm{mM}$ Ethylene glycol bis(2-aminoethyl) tetraacetic acid (EGTA), $10 \mathrm{mM}$ HEPES, $10 \mathrm{mM}$ glucose, and $1 \%$ albumin, and the $\mathrm{pH}$ was adjusted to 7.4 with $\mathrm{KOH}$. The pipette solution contained $20 \mathrm{mM} \mathrm{KCl}$, $110 \mathrm{mM}$ potassium aspartate, $5 \mathrm{mM}$ HEPES, $1 \mathrm{mM} \mathrm{MgCl} 2,10 \mathrm{mM}$ EGTA, $5 \mathrm{mM} \mathrm{Na}_{2}$-ATP, and the $\mathrm{pH}$ was adjusted to 7.2 with $\mathrm{KOH}$. The pipette solution for recording $I_{\mathrm{ca}, \mathrm{L}}$ contained $20 \mathrm{mM} \mathrm{CsCl}$, $110 \mathrm{mM}$ cesium aspartate, $1 \mathrm{mM} \mathrm{MgCl}_{2}, 5 \mathrm{mM}$ HEPES, $10 \mathrm{mM}$ EGTA, and $5 \mathrm{mM} \mathrm{Na}_{2}-\mathrm{ATP}$, and the pH was adjusted to 7.2 with $\mathrm{CsOH}$. The standard bath solution for recording $I_{\mathrm{ca}, \mathrm{L}}$ contained $126 \mathrm{mM}$ choline chloride, $5.4 \mathrm{mM} \mathrm{CsCl}, 1 \mathrm{mM} \mathrm{MgCl}_{2}, 1.8 \mathrm{mM}$ $\mathrm{CaCl}_{2}, 0.33 \mathrm{mM} \mathrm{NaH}_{2} \mathrm{PO}_{4}, 10 \mathrm{mM}$ glucose, and $10 \mathrm{mM}$ HEPES, and the $\mathrm{pH}$ was adjusted to 7.4 with $\mathrm{CsOH}$. Type II collagenase, EGTA, taurine, and bovine serum albumin (BSA) were all purchased from Sigma Chemical Co (St. Louis, MO, USA).

\section{Cell preparation}

As described previously, we isolated single ventricular myocytes from adult rat left ventricles by enzymatic dissociation [11]. Briefly, rats were anesthetized by intraperitoneal injection of sodium pentobarbital $\left(50 \mathrm{mg} \cdot \mathrm{kg}^{-1}\right)$ and heparin $\left(300 \mathrm{U} \cdot \mathrm{kg}^{-1}\right)$. The rat heart was excised, placed on a Langendorff apparatus, and perfused in a retrograde fashion with oxygenated ice-cold $\mathrm{Ca}^{2+}$-free Tyrode's solution through the aorta at a perfusion rate of $4 \mathrm{ml} \cdot \mathrm{min}^{-1}$ for $5 \mathrm{~min}$. The heart was subsequently perfused with $\mathrm{Ca}^{2+}$-free Tyrode's solution with $34 \mu \mathrm{M} \mathrm{CaCl} \mathrm{Ca}_{2}$ and $300 \mathrm{mg} \cdot \mathrm{L}^{-1}$ collagenase II at $37^{\circ} \mathrm{C}$ for $12 \mathrm{~min}$. The left ventricle was removed, cut into $1 \mathrm{~mm}$ pieces, and placed in Krebs solution. Single myocytes were harvested by passing the single cell suspension through a nylon mesh with pore size of $200 \mu \mathrm{m}$. The cells were rested by incubating in Krebs solution at room temperature for $1-3 \mathrm{~h}$. The $\mathrm{Ca}^{2+}$ concentration in the Krebs solution was gradually increased to $1 \mathrm{mM}$ before the experiment.

\section{Whole cell patch clamp experiments}

For whole cell patch clamp experiments, the isolated ventricular myocyte suspension was pipetted into a perfusion chamber that was set on the stage of an inverted microscope (Olympus IX51, Tokyo, Japan). Glass microelectrodes were made as described previously [11]. The ion currents, including sodium, L-type calcium, and transient outward potassium currents, were recorded with an Axopatch 700B amplifier (Axon Instruments, Foster City, CA, USA). The recordings were digitized at $2-10 \mathrm{kHz}$ with the Digit Data 1440A analogue-to-digital converter (Axon Instruments), and the pCLAMP 10.0 software (Axon Instruments) was used to acquire data and analyze traces for the voltage clamp protocols. The whole-cell series resistance was compensated to $>80 \%$, and the current traces were presented as current density $\left(\mathrm{pApF}^{-1}\right)$. All experiments were performed at room temperature $\left(23 \pm 1^{\circ} \mathrm{C}\right)$.

Using the above protocols, whole cell $I_{\mathrm{Na}}$ was tested at potentials ranging from -120 to $+30 \mathrm{mV}$, at $10 \mathrm{mV}$ increments. The $I_{\mathrm{Na}}$ was calculated as the difference between peak inward current and the holding current level. Steady-state activation curves of $I_{\mathrm{Na}}$ were derived from the current-voltage relationship and were fitted according to the Boltzmann equation. The voltage dependent steady-state inactivation of $I_{\mathrm{Na}}$ was defined by applying a $50 \mathrm{~ms}$ conditioning pulse, ranging from $-150 \mathrm{mV}$ to $+30 \mathrm{mV}$ in $10 \mathrm{mV}$ increments, followed by a $25 \mathrm{~ms}$ test pulse to $-30 \mathrm{mV}$. The data were fitted using the Boltzmann distribution equation. Whole cell $I_{\mathrm{Ca}, \mathrm{L}}$ was elicited from a holding potential of $-40 \mathrm{mV}$ and tested with potentials ranging from -40 to $+60 \mathrm{mV}$, in $10 \mathrm{mV}$ increments. $I_{\mathrm{Ca}, \mathrm{L}}$ was calculated as the difference between peak inward and holding current. The steady-state activation curve of $I_{\mathrm{Ca}, \mathrm{L}}$ was derived from the current-voltage relationships and fitted to the Boltzmann equation. The voltage dependent steady-state inactivation of $I_{\mathrm{Ca}, \mathrm{L}}$ was determined by applying a $1000 \mathrm{~ms}$ conditioning pulse ranging from -40 to $+20 \mathrm{mV}$, in $10 \mathrm{mV}$ increments, followed by a $150 \mathrm{~ms}$ test pulse to $0 \mathrm{mV}$, with a holding potential of $-40 \mathrm{mV}$. The data were fitted to the Boltzmann distribution equation. Whole cell $I_{\text {to }}$ was elicited from a holding potential of $-50 \mathrm{mV}$, with test potentials ranging from -50 to $+65 \mathrm{mV}$, in $5 \mathrm{mV}$ increments. The outward peak amplitude was $I_{\text {to }}$, which was the major repolarizing potassium current in rat ventricular myocytes. The steady-state activation curve of $I_{\text {to }}$ was derived from the currentvoltage relationship and fitted according to the Boltzmann equation. The voltage dependent steady-state inactivation of $I_{\text {to }}$ was calculated by applying $500 \mathrm{~ms}$ prepulses from -120 to $+30 \mathrm{mV}$ prior to pulsing to a $\mathrm{Vm}$ of $+60 \mathrm{mV}$. Steady-state inactivation curves were constructed by normalizing the measured $I_{\text {to }}$ after each prepulse (I/Imax) and plotting the values against the prepulse voltage. The curves were fitted to the Boltzmann equation to derive steady-state inactivation parameters $\mathrm{V}_{1 / 2}$ and $\mathrm{k}$. 
Table 1 Effects of taurine-magnesium coordination compound (TMCC) and amiodarone on the currents, steady-state activation and inactivation of abnormal sodium channel induced by hypoxia/reoxygenation $(\mathrm{H} / \mathrm{R})$ in rat isolated ventricular myocytes.

\begin{tabular}{|c|c|c|c|c|c|}
\hline Groups & $I_{\mathrm{Na}}(\mathrm{pA} / \mathrm{pF})$ & $\mathrm{V}_{1 / 2 \text { (act) }} / \mathrm{mV}$ & $\mathbf{K}_{\text {act }}$ & $\mathrm{V}_{1 / 2 \text { (inact) } / \mathrm{mV}}$ & $K_{\text {inact }}$ \\
\hline control & $-56.89 \pm 2.07^{\# \#}$ & $-82.98 \pm 1.64^{\#}$ & $4.13 \pm 0.61$ & $-127.04 \pm 1.83^{\# \#}$ & $5.90 \pm 0.55^{\#}$ \\
\hline$H / R$ & $-35.05 \pm 1.52^{* *}$ & $-74.94 \pm 3.74^{*}$ & $3.75 \pm 0.59$ & $-140.71 \pm 1.25^{* *}$ & $8.16 \pm 0.98^{*}$ \\
\hline $\mathrm{H} / \mathrm{R}+200 \mu \mathrm{M}$ TMCC & $-41.52 \pm 0.86^{* * \# \#}$ & $-77.21 \pm 2.57^{*}$ & $4.45 \pm 0.54$ & $-137.41 \pm 1.14^{* * \#}$ & $7.78 \pm 0.84^{*}$ \\
\hline $\mathrm{H} / \mathrm{R}+400 \mu \mathrm{M} T \mathrm{TMCC}$ & $-48.34 \pm 0.99^{* * \# \#}$ & $-78.82 \pm 1.44^{*}$ & $4.75 \pm 0.63$ & $-133.06 \pm 2.99^{\#}$ & $7.42 \pm 0.87$ \\
\hline $\mathrm{H} / \mathrm{R}+40 \mu \mathrm{M}$ amiodarone & $-39.44 \pm 1.24^{* * \# \#}$ & $-78.88 \pm 1.19^{*}$ & $4.86 \pm 0.31$ & $-136.25 \pm 1.54^{* * \# \#}$ & $8.35 \pm 0.78^{* *}$ \\
\hline
\end{tabular}

$\mathrm{n}=6$ per group; ${ }^{*} \mathrm{P}<0.05$ vs. control group, ${ }^{* *} \mathrm{P}<0.01$ vs. control group, $\# \mathrm{P}<0.05$ vs. $\mathrm{H} / \mathrm{R}$ group, $\# \# \mathrm{P}<0.01$ vs. $\mathrm{H} / \mathrm{R}$ group

To record the sodium current, cadmium chloride $(0.3 \mathrm{mM})$ was added to the external solution to block the $I_{\mathrm{Ca}-\mathrm{L}}$ current, and the maximum sodium current $\left(I_{\mathrm{Na} \text {,max }}\right)$ was observed at $-60 \mathrm{mV}$. To record the calcium current, the magnitude of $I_{\mathrm{ca}, \mathrm{L}}$ was measured as the peak inward current and the maximum calcium current $\left(I_{\text {ca,L,max }}\right)$ was observed at $15 \mathrm{mV}$. To record transient outward potassium currents, $0.2 \mathrm{mM} \mathrm{Cd}^{2+}$ and $0.2 \mu \mathrm{M} \mathrm{Ba}^{2+}$ were used to block $I_{\mathrm{ca}, \mathrm{L}}$ and $I_{\mathrm{k} 1}$, respectively, the maximum transient outward potassium current $\left(I_{\mathrm{to}, \max }\right)$ was observed at $50 \mathrm{mV}$. The standard bath solution was replaced with a bath solution filled with $\mathrm{N}_{2}$ to simulate hypoxia. After $15 \mathrm{~min}$ of hypoxia, the $\mathrm{N}_{2}$ bath solution was replaced with a bath solution filled with $\mathrm{O}_{2}$ to simulate reperfusion. The change in densities of $I_{\mathrm{Na}, \text { max }}, I_{\mathrm{Ca}, \mathrm{L}, \max }$ and $I_{\mathrm{to}, \max }$ were measured after single ventricular myocytes were exposed to $\mathrm{H} / \mathrm{R}$ for 10 min. TMCC was administered after exposed to $\mathrm{H} / \mathrm{R}$ and the $I_{\mathrm{Na}, \max }, I_{\mathrm{Ca}, \mathrm{L}, \max }$ and $I_{\mathrm{to}, \max }$ were measured $10 \mathrm{~min}$ after treatment.

\section{Statistical analysis}

Data were presented as mean \pm standard error of the mean. Curve fitting was made using pCLAMP 10.0 (Axon Instruments) or software Origin 6.0 (Microcal Software, Northampton, MA, USA). Statistical significance was analyzed using a 2-tailed paired Student's $t$-test for comparisons of 2 means or analysis of variance (ANOVA) for comparison of multiple means. A $P$ value $<0.05$ was considered statistically significant.

\section{Results}

$\nabla$

TMCC prevented abnormal sodium channels induced by $H / R$ in rat ventricular myocytes

As shown in $\odot$ Table 1, at a $-60 \mathrm{mV}$ test pulse, sodium current density decreased from $-56.89 \pm 2.07 \mathrm{pApF}^{-1}$ to $-35.05 \pm 1.52$ $\mathrm{pApF}^{-1}$ ( $\mathrm{n}=6$ per group, $\mathrm{P}<0.01$ vs. control). Following $\mathrm{H} / \mathrm{R}$ injury, the peak inward sodium current decreased by $38 \%$ $(\mathrm{P}<0.05$ vs. control). TMCC $(200$ or $400 \mu \mathrm{M})$ or amiodarone $(40 \mu \mathrm{M})$ restored the decreased sodium currents induced by $\mathrm{H} / \mathrm{R}$ from $-35.05 \pm 1.52 \mathrm{pApF}^{-1}$ to $-41.52 \pm 0.86 \mathrm{pApF}^{-1},-48.34 \pm 0.99$ $\mathrm{pApF}^{-1}$ and $-39.44 \pm 1.24 \mathrm{pApF}^{-1}$, respectively. ( $\mathrm{n}=6$ per group, $P<0.01$ vs. $\mathrm{H} / \mathrm{R})$.

As shown in $\odot$ Table $\mathbf{1}, \odot$ Fig. $\mathbf{2 g}$, h, steady-state activation and inactivation curves of the abnormal sodium channels obtained following $\mathrm{H} / \mathrm{R}$ injury before and after TMCC treatment. The H/R group shifted the half activation potential from $-82.98 \pm 1.64 \mathrm{mV}$ to $-74.94 \pm 3.74 \mathrm{mV}$ ( $\mathrm{n}=6$ per group, $P<0.05$ vs. control), and the slope parameter ( $\mathrm{K}$ ) was not affected. Neither TMCC nor amiodarone shifted any of the activation parameters. The H/R group shifted the half inactivation potential from $-127.04 \pm 1.83 \mathrm{mV}$ to $-140.71 \pm 1.25 \mathrm{mV}$ ( $\mathrm{n}=6$ each group, $P<0.01$ vs. control) and the slope parameter ( $\mathrm{K}$ ) from $5.90 \pm 0.55 \mathrm{mV}$ to $8.16 \pm 0.98 \mathrm{mV}$
( $\mathrm{n}=6$ per group, $P<0.05$ vs. control). TMCC or amiodarone shifted the half inactivation potential from $-140.71 \pm 1.25 \mathrm{mV}$ to $-137.41 \pm 1.14 \mathrm{mV},-133.06 \pm 2.99 \mathrm{mV} \quad(\mathrm{n}=6$ per group, $P<0.05$ vs. $\mathrm{H} / \mathrm{R}$ ) and $-136.25 \pm 1.54 \mathrm{mV}(\mathrm{n}=6$ per group, $P<0.01$ vs. $H / R)$. However, the slope parameter $(K)$ was not changed significantly between the $H / R$ group and any of the drug treatment groups.

TMCC prevented abnormal L-type calcium channels induced by $H / R$ in rat ventricular myocytes

As shown in $\odot$ Table 2, at a $10 \mathrm{mV}$ test pulse, the calcium current density increased from $-3.35 \pm 0.62 \mathrm{pApF}^{-1}$ to $-5.69 \pm 0.25$ $\mathrm{pApF}^{-1}$ ( $\mathrm{n}=6$ per group, $P<0.01$ vs. control). Following $\mathrm{H} / \mathrm{R}$ injury, the peak inward calcium currents increased significantly by $41 \%$ ( $\mathrm{p}<0.05 \mathrm{vs}$. control). TMCC or amiodarone restored the abnormal calcium currents by increasing the currents from $-5.69 \pm 0.25 \mathrm{pApF}^{-1}$ to $-4.41 \pm 0.22 \mathrm{pApF}^{-1}$ and $-3.82 \pm 0.21$ $\mathrm{pApF}^{-1}$ for TMCC (at the 200 and $400 \mu \mathrm{M}$ concentrations, respectively) and to $-3.66 \pm 0.27 \mathrm{pApF}^{-1}$ for amiodarone $(\mathrm{n}=6$ per group, $P<0.01$ vs. $\mathrm{H} / \mathrm{R})$.

The steady-state activation and inactivation curves of abnormal calcium channels obtained following $\mathrm{H} / \mathrm{R}$ injury before and after TMCC treatment are shown in $\odot$ Table $\mathbf{2}$, $\odot$ Fig. $\mathbf{3 g}$, h. The H/R group shifted the half activation potential from $-12.63 \pm 0.69 \mathrm{mV}$ to $-17.12 \pm 0.65 \mathrm{mV}$ ( $\mathrm{n}=6$ per group, $P<0.01$ vs. control) and the slope parameter $(\mathrm{K})$ from $7.10 \pm 0.48 \mathrm{mV}$ to $8.84 \pm 0.47 \mathrm{mV}$ ( $\mathrm{n}=6$ per group, $P<0.01$ vs. control). TMCC or amiodarone shifted the half activation potential from $-17.12 \pm 0.65 \mathrm{mV}$ to $-14.63 \pm 0.85 \mathrm{mV}$ and $-12.87 \pm 1.09 \mathrm{mV}$ for TMCC (at the 200 and $400 \mu \mathrm{M}$ concentrations, respectively) and to $-13.15 \pm 0.84 \mathrm{mV}$ for amiodarone ( $\mathrm{n}=6$ per group, $P<0.01$ vs. $\mathrm{H} / \mathrm{R}$ ). However, the slope parameter $(\mathrm{K})$ was not significantly changed. The $\mathrm{H} / \mathrm{R}$ group shifted the half inactivation potential from $-22.67 \pm 0.73 \mathrm{mV}$ to $-16.24 \pm 0.89 \mathrm{mV}$ ( $\mathrm{n}=6$ per group, $P<0.01$ vs control), and the slope parameter ( $\mathrm{K})$ from $7.60 \pm 0.35 \mathrm{mV}$ to $5.80 \pm 0.75 \mathrm{mV}$ ( $\mathrm{n}=6$ per group, $P<0.05$ vs. control). TMCC or amiodarone shifted the half inactivation potential from $-16.24 \pm 0.89 \mathrm{mV}$ to $-20.76 \pm 0.29 \mathrm{mV}$ and $-22.77 \pm 0.75 \mathrm{mV}$ for TMCC (at the 200 and $400 \mu \mathrm{M}$ concentrations, respectively) and to $-22.10 \pm 0.40 \mathrm{mV}$ for amiodarone ( $\mathrm{n}=6$ per group, all $P<0.01$ vs. $\mathrm{H} / \mathrm{R})$. However, the slope parameter $(\mathrm{K})$ was not significantly changed.

\section{TMCC prevented abnormal transient outward} potassium channels induced by $H / R$ in rat ventricular myocytes

As shown in $\odot$ Table 3, at a $50 \mathrm{mV}$ test pulse, the $I_{\text {to,max }}$ density was increased from $8.40 \pm 0.66 \mathrm{pApF}^{-1}$ to $13.50 \pm 0.41 \mathrm{pApF}^{-1}$ ( $n=6$ per group, $P<0.01$ vs. control). Following H/R injury, the peak current density of the transient outward potassium currents was significantly increased by $38 \%$. TMCC (at the 200 and $400 \mu \mathrm{M}$ concentrations) or amiodarone prevented the increase 


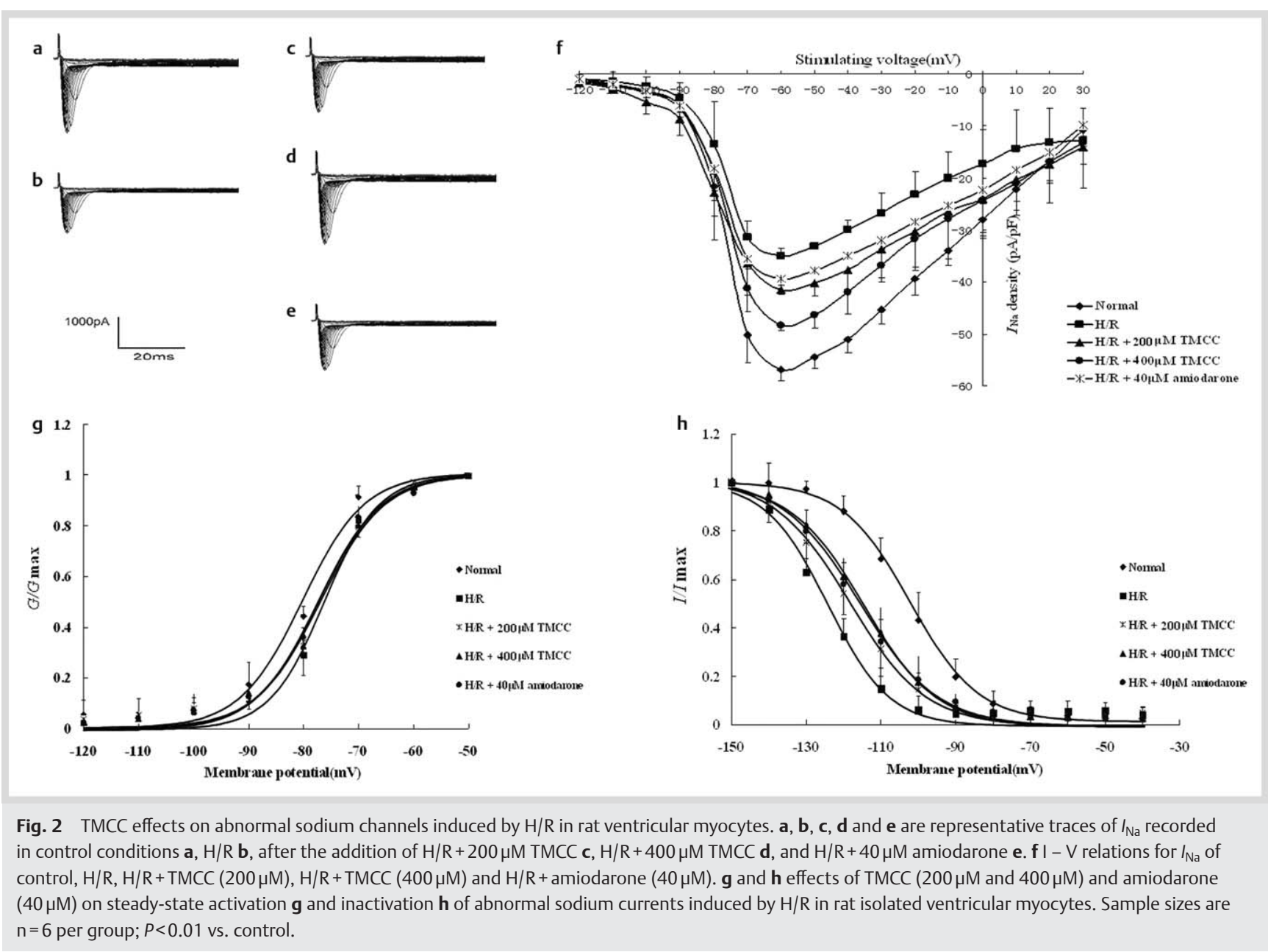

Table 2 Effects of taurine-magnesium coordination compound (TMCC) and amiodarone on the currents, steady-state activation and inactivation of abnormal L-type calcium channel induced by hypoxia/reoxygenation $(H / R)$ in rat isolated ventricular myocytes.

\begin{tabular}{|c|c|c|c|c|c|}
\hline Groups & $I_{\mathrm{Ca}, \mathrm{L}}(\mathrm{pA} / \mathrm{pF})$ & $\mathrm{V}_{1 / 2 \text { (act) }} / \mathrm{mV}$ & $\mathrm{K}_{\mathrm{act}}$ & $V_{1 / 2 \text { (inact) }} / m V$ & $K_{\text {inact }}$ \\
\hline control & $-3.35 \pm 0.50^{\# \#}$ & $-12.63 \pm 0.69^{\# \#}$ & $7.10 \pm 0.48^{\# \#}$ & $-22.67 \pm 0.73^{\# \#}$ & $7.60 \pm 0.35^{\#}$ \\
\hline$H / R$ & $-5.69 \pm 0.25^{* *}$ & $-17.12 \pm 0.65^{* *}$ & $8.84 \pm 0.47^{* *}$ & $-16.24 \pm 0.89^{* *}$ & $5.80 \pm 0.75^{*}$ \\
\hline $\mathrm{H} / \mathrm{R}+200 \mu \mathrm{M}$ TMCC & $-4.41 \pm 0.22^{* \# \#}$ & $-14.63 \pm 0.85^{* \# \#}$ & $8.11 \pm 0.59$ & $-20.76 \pm 0.29 * \# \#$ & $6.19 \pm 0.98$ \\
\hline $\mathrm{H} / \mathrm{R}+400 \mu \mathrm{M} T \mathrm{TMCC}$ & $-3.82 \pm 0.21^{\# \#}$ & $-12.87 \pm 1.09^{\# \#}$ & $7.57 \pm 0.18$ & $-22.77 \pm 0.75^{\# \#}$ & $6.23 \pm 0.98$ \\
\hline $\mathrm{H} / \mathrm{R}+40 \mu \mathrm{M}$ amiodarone & $-3.66 \pm 0.27^{\# \#}$ & $-13.15 \pm 0.84^{\# \#}$ & $7.50 \pm 0.70$ & $-22.10 \pm 0.40^{\# \#}$ & $6.54 \pm 0.62$ \\
\hline
\end{tabular}

in transient outward potassium currents induced by $\mathrm{H} / \mathrm{R}$ from $13.50 \pm 0.41 \mathrm{pApF}^{-1}$ to $10.60 \pm 0.84 \mathrm{pApF}^{-1}$ and $7.80 \pm 0.15$ $\mathrm{pApF}^{-1}$ for the 200 and $400 \mu \mathrm{M}$ concentrations of TMCC, respectively, and to $7.93 \pm 0.43 \mathrm{pApF}^{-1}$ for amiodarone $(n=6$ per group, all $P<0.01$ vs. $H / R)$.

The steady-state activation and inactivation curves of abnormal transient outward potassium channels obtained following $H / R$ injury before and after TMCC treatment are shown in - Table 3, Fig. 4g, h. The H/R group shifted the half activation potential from $25.51 \pm 1.58 \mathrm{mV}$ to $21.80 \pm 1.03 \mathrm{mV}(\mathrm{n}=6, P<0.01$ vs. control), but the slope parameter ( $\mathrm{K}$ ) was not significantly changed. TMCC or amiodarone shifted the half activation potential from $21.80 \pm 1.03 \mathrm{mV}$ to $23.33 \pm 2.92 \mathrm{mV}$ and $27.04 \pm 0.60 \mathrm{mV}$ for TMCC and to $24.17 \pm 1.06 \mathrm{mV}$ for amiodarone $(\mathrm{n}=6, P<0.01$ vs. $H / R$ ), but the slope parameter $(\mathrm{K})$ was not significantly changed. The half inactivation potential and the slope parameter (K) were also not significantly changed between the H/R group and any of the drug treatment groups.

\section{Discussion}

TMCC has been used effectively as an antiarrhythmic agent in vivo. The mechanisms underlying its actions, however, have not been fully described. The major findings of the current study were TMCC prevented abnormal sodium channel, L-type calcium channel and transient outward potassium channel induced by $H / R$ in single rat ventricular myocytes.

Ischemia/reperfusion injury is known to stimulate structural and functional remodeling of the left ventricle. This remodeling enhances the arrhythmic potential of the myocardium and increases the chance of sudden cardiac death. Both the ischemic and reoxygenation phases perturb normal cardiac myocyte function. Previous studies have assigned roles for $\mathrm{K}^{+}$channels, voltage-dependent L-type $\mathrm{Ca}^{2+}$ channels, $\mathrm{Na}^{+} / \mathrm{Ca}^{2+}$ exchanger, and sarcoplasmic reticulum $\mathrm{Ca}^{2+}$-ATPase pump, and ryanodine receptors [14-19]. Our previous studies showed that TMCC could inhibit sodium currents and transient outward potassium 

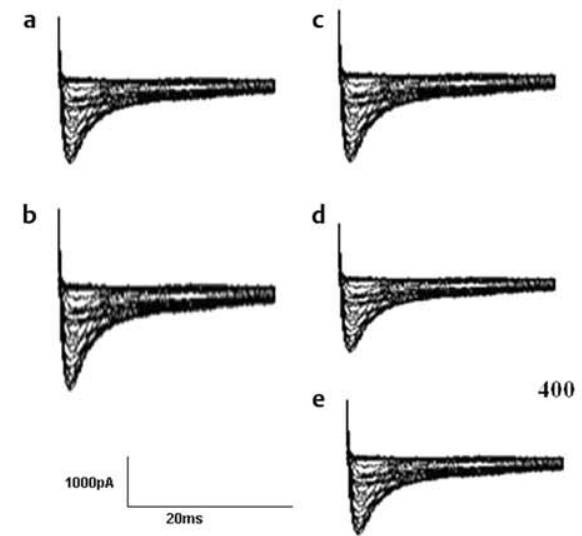

400

$\mu \mathrm{M}$ TMCC
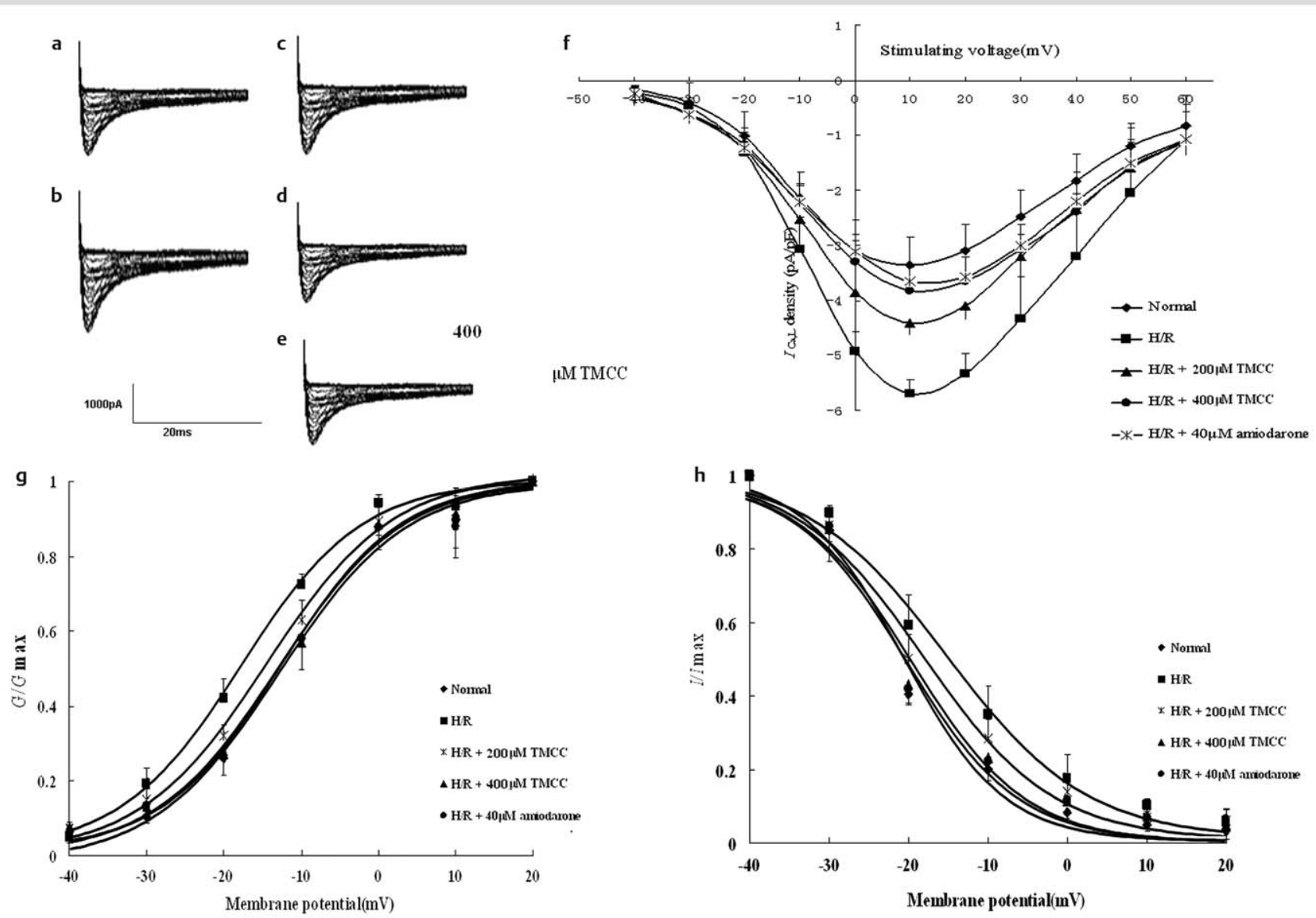

Fig. 3 TMCC effects on abnormal L-type calcium channels induced by $H / R$ in rat ventricular myocytes. $\mathbf{a}, \mathbf{b}, \mathbf{c}, \mathbf{d}$ and $\mathbf{e}$ are representative traces of $I_{\mathrm{Ca}, \mathrm{L}}$ recorded in control conditions $\mathbf{a}, \mathrm{H} / \mathrm{R} \mathbf{b}$, after the addition of $\mathrm{H} / \mathrm{R}+200 \mu \mathrm{M} \mathrm{TMCC} \mathbf{c}, \mathrm{H} / \mathrm{R}+400 \mu \mathrm{M}$ TMCC $\mathbf{d}$, and $\mathrm{H} / \mathrm{R}+40 \mu \mathrm{M}$ amiodarone $\mathbf{e}$. $\mathbf{f} \mathrm{I}-\mathrm{V}$ relations for $I_{\mathrm{Ca}, \mathrm{L}}$ of control, H/R, H/R+TMCC $(200 \mu \mathrm{M}), \mathrm{H} / \mathrm{R}+\mathrm{TMCC}(400 \mu \mathrm{M})$ and $\mathrm{H} / \mathrm{R}+$ amiodarone $(40 \mu \mathrm{M})$. $\mathbf{g}$ and $\mathbf{h}$ effects of TMCC $(200 \mu \mathrm{M}$ and $400 \mu \mathrm{M})$ and amiodarone $(40 \mu \mathrm{M})$ on steady -state activation $\mathbf{g}$ and inactivation $\mathbf{h}$ of abnormal L-type calcium currents induced by $\mathrm{H} / \mathrm{R}$ in rat isolated ventricular myocytes. Sample sizes are $\mathrm{n}=6$ per group and $P<0.01$ vs. control.

Table 3 Effects of taurine-magnesium coordination compound (TMCC) and amiodarone on the currents, steady-state activation and inactivation of abnormal transient outward potassium channel induced by hypoxia/reoxygenation $(H / R)$ in rat isolated ventricular myocytes.

\begin{tabular}{|c|c|c|c|c|c|}
\hline Groups & to $(\mathrm{pA} / \mathrm{pF})$ & $\mathrm{V}_{1 / 2 \text { (act) }} / \mathrm{mV}$ & $\mathbf{K}_{\text {act }}$ & $\mathrm{V}_{1 / 2 \text { (inact) }} / \mathrm{mV}$ & $K_{\text {inact }}$ \\
\hline control & $8.40 \pm 0.66^{\# \#}$ & $25.51 \pm 1.58^{\# \#}$ & $10.89 \pm 0.77$ & $-29.50 \pm 0.78$ & $3.98 \pm 0.35$ \\
\hline$H / R$ & $13.50 \pm 0.41^{* *}$ & $21.80 \pm 1.03^{* *}$ & $11.02 \pm 0.43$ & $-29.33 \pm 0.56$ & $3.89 \pm 0.31$ \\
\hline $\mathrm{H} / \mathrm{R}+200 \mu \mathrm{M}$ TMCC & $10.60 \pm 0.84^{* * \# \#}$ & $23.33 \pm 2.92^{\# \#}$ & $11.43 \pm 0.67$ & $-30.96 \pm 0.19$ & $3.92 \pm 0.29$ \\
\hline $\mathrm{H} / \mathrm{R}+400 \mu \mathrm{M}$ TMCC & $7.80 \pm 0.15^{\# \#}$ & $27.04 \pm 0.60^{\# \#}$ & $11.44 \pm 0.33$ & $-30.45 \pm 1.07$ & $3.93 \pm 0.27$ \\
\hline $\mathrm{H} / \mathrm{R}+40 \mu \mathrm{M}$ amiodarone & $7.93 \pm 0.43^{\# \#}$ & $24.17 \pm 1.06^{\# \#}$ & $10.79 \pm 0.70$ & $-30.98 \pm 0.79$ & $3.95 \pm 0.62$ \\
\hline
\end{tabular}

$\mathrm{n}=6$ per group; ${ }^{* *} \mathrm{P}<0.01$ vs. control group, \#\# $\mathrm{P}<0.01$ vs. $\mathrm{H} / \mathrm{R}$ group

currents, concomitant with a moderate increase in L-type calcium currents [11]. From that study, we concluded that $I_{\mathrm{Na}}, I_{\mathrm{Ca}, \mathrm{L}}$, and $I_{\text {to }}$ may be key factors involved in the development arrhythmias. Here, we extend the previous study to determine the effects of TMCC on these abnormal channels induced hypoxia/ reoxygenation.

The excitability of cardiac ventricular myocytes is critically regulated by the voltage-gated $\mathrm{Na}^{+}$channel. As such, the voltagegated $\mathrm{Na}^{+}$channel is a primary target of several neurotoxins as well as therapeutic agents. Therapeutic agents that have been shown to be efficacious against the voltage-gated $\mathrm{Na}^{+}$channel include quinidine, lidocaine, and phenytoin [20]. Our previous study showed that $I_{\mathrm{Na}}$ was blocked by TMCC in a concentrationdependent manner, and the effects of TMCC $(400 \mu \mathrm{M})$ were equal to that of amiodarone. TMCC inhibited $I_{\mathrm{Na}}$ through retardation of steady-state activation and steady-state inactivation [11]. Our results showed that sodium currents were significantly decreased by $\mathrm{H} / \mathrm{R}$, which shifted steady-state activation curves to the right and inactivation curves to the left. These results suggest that the steady-state activation of the $\mathrm{Na}^{+}$channel was decelerated while the inactivation was accelerated. The $H / R$ group may inhibit $I_{\mathrm{Na}}$ by blocking the steady-state activation and facilitating the steady-state inactivation. TMCC or amiodarone restored sodium currents significantly. The effect of amiodarone, however, was not as potent as the effect of TMCC. After H/R injury, TMCC or amiodarone shifted the steady-state inactivation curves to the right, while TMCC or amiodarone failed to alter the steady-state activation curves, suggesting that the 


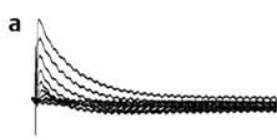

b

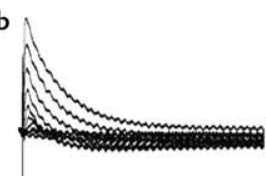

d
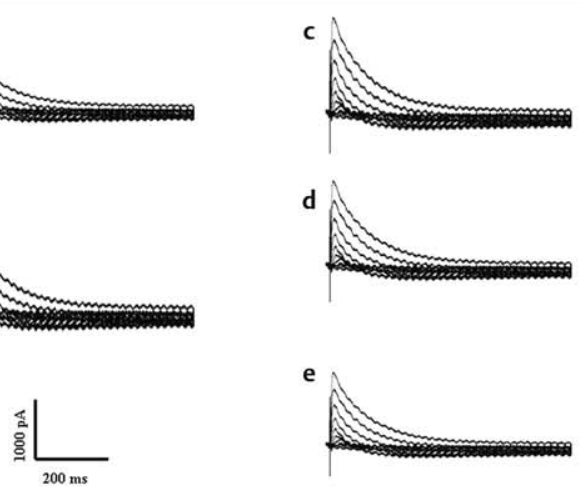

g

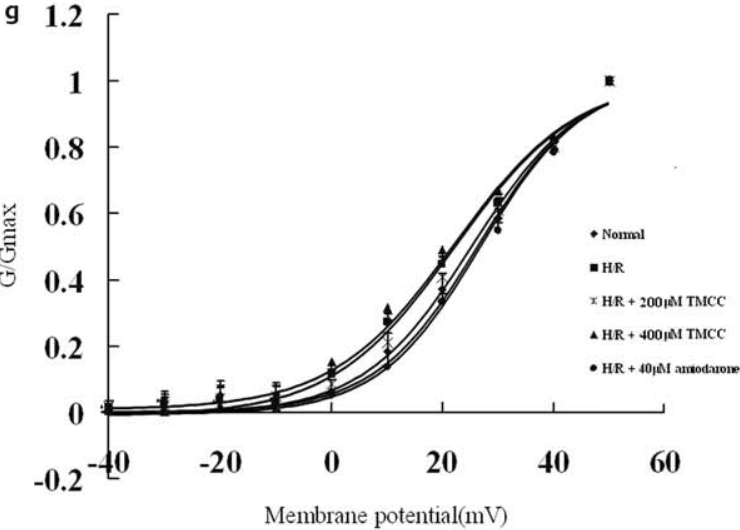

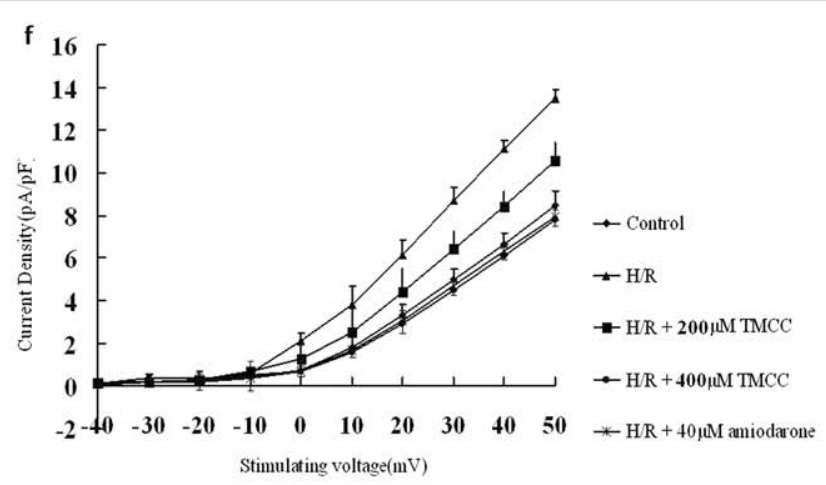

h 1.2

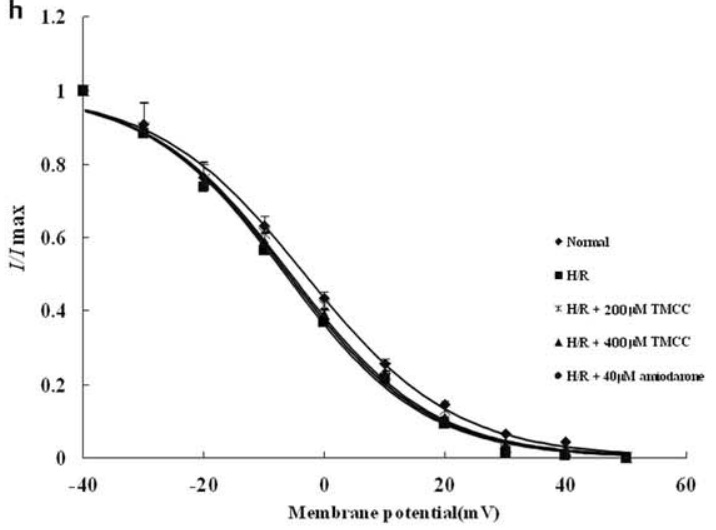

Fig. 4 TMCC effects on abnormal transient outward potassium channels induced by $\mathrm{H} / \mathrm{R}$ in rat ventricular myocytes. $\mathbf{a}, \mathbf{b}, \mathbf{c}$, $\mathbf{d}$ and $\mathbf{e}$ are representative traces of $I_{\text {to }}$ recorded in control conditions a, $\mathrm{H} / \mathrm{R} \mathbf{b}$, after the addition of $\mathrm{H} / \mathrm{R}+200 \mu \mathrm{M} \mathrm{TMCC} \mathbf{c}, \mathrm{H} / \mathrm{R}+400 \mu \mathrm{M} \mathrm{TMCC} \mathbf{d}$, and $\mathrm{H} / \mathrm{R}+40 \mu \mathrm{M}$ amiodarone $\mathbf{e}$. $\mathbf{f I}-\mathrm{V}$ relations for $I_{\text {to }}$ of control, H/R, H/R+TMCC $(200 \mu \mathrm{M}), \mathrm{H} / \mathrm{R}+\mathrm{TMCC}(400 \mu \mathrm{M})$ and $\mathrm{H} / \mathrm{R}+$ amiodarone $(40 \mu \mathrm{M}) . \mathbf{g}$ and $\mathbf{h}$ effects of TMCC $(200 \mu \mathrm{M}$ and $400 \mu \mathrm{M})$ and amiodarone $(40 \mu \mathrm{M})$ on steady-state activation $\mathbf{g}$ and inactivation $\mathbf{h}$ of abnormal transient outward potassium currents induced by $\mathrm{H} / \mathrm{R}$ in rat isolated ventricular myocytes. Sample sizes are $\mathrm{n}=6$ per group and $P<0.01$ vs. control.

steady-state inactivation of the sodium channel was decelerated. Taken together, these results provide electrophysiological evidence that TMCC prevents abnormal sodium currents induced by $\mathrm{H} / \mathrm{R}$ by altering the steady-state inactivation kinetics.

In ventricular myocytes, the generation of action potentials is facilitated by the L-type $\mathrm{Ca}^{2+}$ channels under both physiological and pathophysiological conditions [21-23]. Our group has previously shown that TMCC increases $I_{\mathrm{C}_{\mathrm{a}} \mathrm{L}}$ activity, which has subsequent positive inotropic effects $[12,13]$. In contrast, established anti-arrhythmia drugs operate through a separate mechanism, indicating that TMCC and established drugs will have non-overlapping effects. Our results showed that the H/R group significantly increased L-type calcium currents, and this effect was blunted by TMCC treatment. The H/R group shifted the steadystate activation curves to the left and shifted inactivation curves to the right, suggesting that the voltage-dependent steady-state activation of L-type $\mathrm{Ca}^{2+}$ channel was accelerated and inactivation of L-type $\mathrm{Ca}^{2+}$ channels was decelerated. These data suggested that the $\mathrm{H} / \mathrm{R}$ group increased $I_{\mathrm{Ca}, \mathrm{L}}$ by facilitating of steady-state activation and inhibiting of steady-state inactivation. Both doses of TMCC or amiodarone restored abnormal L-type calcium currents by decreasing the effect of H/R. TMCC at the $400 \mu \mathrm{M}$ dose showed effects similar to that of amiodarone. Following H/R injury, TMCC or amiodarone shifted the steadystate activation curves to the right and shifted the steady-state inactivation curve to the left, suggesting that the steady-state activation of the L-type calcium channel was decelerated and inactivation of the L-type calcium channel was accelerated. Our results provide electrophysiological evidence that TMCC prevents abnormal L-type calcium currents induced by $H / R$ by inhibiting steady-state activation and facilitating steady-state inactivation.

$I_{\text {to }}$ is the predominant repolarizing potassium current in rat ventricular myocytes [24]. Following depolarization, cardiac $I_{\text {to }}$ channels activate and inactivate rapidly, and this response is necessary to maintain the resting membrane potential [24]. Depolarization is a key mechanism whereby ventricular arrhythmias in induced in pathophysiological setting, and preventing abnormal depolarization is the major target of Class III antiarrhythmic drugs [25]. Being able to inhibit $I_{\text {to }}$ channels could potentially be therapeutically efficacious to prevent or suppress reentrant arrhythmias [26-28]. The result of the present study showed that transient outward potassium currents were significantly increased by $H / R$. The $H / R$ group shifted steady-state activation to the left, while failed to alter the steadystate inactivation curves, suggesting that the steady-state activation of $I_{\text {to }}$ channel was accelerated. These data suggested that the $\mathrm{H} / \mathrm{R}$ group increased $I_{\text {to }}$ through facilitation of steady-state activation. TMCC or amiodarone restored transient outward potassium currents significantly, which were increased by $H / R$. The effect of TMCC was equivalent to that of amiodarone. After $\mathrm{H} / \mathrm{R}$ injury, TMCC and amiodarone shifted the steady-state activation curves to the right and failed to alter the steady-state inactivation curves, suggesting that the steady-state activation was decelerated. Our study provides electrophysiological evidence that TMCC prevents abnormal transient outward potassium cur- 
rents induced by $\mathrm{H} / \mathrm{R}$ by blocking steady-state activation at relatively higher concentrations. It is important to note that our study did not distinguish between the fast $\left(I_{\mathrm{to}}, \mathrm{f}\right)$ and slow $\left(I_{\mathrm{to}}, \mathrm{S}\right)$ components, and differences between these channels should be evaluated in future studies.

In conclusion, the results of this study demonstrate that TMCC can significantly relieve the effect of hypoxia/reoxygenation by modifying sodium, L-type calcium, and transient outward potassium channels. The predominant effect was to reverse the ionic balance in ventricular myocytes disrupted by H/R. Meanwhile, compared with amiodarone, the effect of TMCC prevented abnormal sodium currents induced by $\mathrm{H} / \mathrm{R}$ was more potent than the effect of amiodarone. TMCC, accordingly, may be used as a multi-target antiarrhythmic drug in the future and a useful agent to prevent arrhythmias in the setting of ischemia and reperfusion.

\section{Acknowledgments}

This work is supported by National Natural Science Foundation of China (No. 30672458). We appreciate the valuable comments from other members of our laboratories.

Sources of financial support: None

\section{Conflict of Interest}

\section{$\nabla$}

None.

\section{References}

1 Hanna J, Chahine R, Aftimos $G$ et al. Protective effect of taurine against free radicals damage in the rat myocardium. Exp Toxicol Pathol 2004; 56: 189-194

2 Coates BJ, Broderick TL, Batia LM et al. MgSO4 prevents left ventricular dysfunction in an animal model of preeclampsia. Am J Obstet Gynecol 2006; 195: 1398-1403

3 Standley CA, Batia L, Yueh G. Magnesium sulfate effectively reduces blood pressure in an animal model of preeclampsia. J Matern Fetal Neonatal Med 2006; 19: 171-176

4 Lee NY, Kang YS. Regulation of taurine transport at the blood-placental barrier by calcium ion, PKC activator and oxidative stress conditions. J Biomed Sci 2010; 17: S37

5 Kang YS. Downregulation of taurine transport by calcium blockers in osteoblast cells. Ady Exp Med Biol 2009; 643: 513-521

6 Beyranvand MR, Khalafi MK, Roshan VD et al. Effect of taurine supplementation on exercise capacity of patients with heart failure. J Cardiol 2011; 57: 333-337

7 Bkaily G, Jaalouk D, Sader S et al. Taurine indirectly increases Ca]i by inducing $\mathrm{Ca} 2+$ influx through the $\mathrm{Na}(+)-\mathrm{Ca} 2+$ exchanger. Mol Cell Biochem 1998; 188: 187-197
8 Shimosawa T, Fujita T. Magnesium and N-type calcium channel. Clin Calcium 2005; 15: 239-244

9 Liu H, Chen H, Yang X. Protective effect of magnesium on ionic channels in guinea pig ventricular myocytes during hypoxia. Zhonghua Yi Xue Za Zhi 1997; 77: 505-508

10 Yin $Y$, Wen $K, W u$ Y et al. Inhibition of Sodium Current by Taurine Magnesium Coordination Compound Prevents Cesium Chloride-Induced Arrhythmias. Biol Trace Elem Res 2012; 146: 192-198

11 Zhao L, Lou J, Wu H et al. Effects of Taurine-Magnesium Coordination Compound on Ionic Channels in Rat Ventricular Myocytes of Arrhythmia Induced by Ouabain. Biol Trace Elem Res 2012; 147: 275-284

12 Li Q Li Z, Mei Y et al. Neuregulin attenuated cerebral ischemia-reperfusion injury via inhibiting apoptosis and upregulating aquaporin-4. Neurosci Lett 2008; 443: 155-159

13 Li C, Jackson RM. Reactive species mechanisms of cellular hypoxiareoxygenation injury. Am J Physiol Cell Physiol 2002; 282: C227-C241

14 Platoshyn $\mathrm{O}, \mathrm{Yu}$ Y, Golovina VA et al. Chronic hypoxia decreases $\mathrm{K}(\mathrm{V})$ channel expression and function in pulmonary artery myocytes. Am J Physiol Lung Cell Mol Physiol 2001; 280: L801-L812

15 Fearon IM, Palmer AC, Balmforth AJ et al. Modulation of recombinant human cardiac L-type $\mathrm{Ca} 2+$ channel alpha1C subunits by redox agents and hypoxia. J Physiol 1999; 514 (Pt 3): 629-637

16 Wang YX, Dhulipala PK, Kotlikoff MI. Hypoxia inhibits the $\mathrm{Na}(+) /$ $\mathrm{Ca}(2+)$ exchanger in pulmonary artery smooth muscle cells. FASEB J 2000; 14: 1731-1740

17 Rowe GT, Manson NH, Caplan M et al. Hydrogen peroxide and hydroxyl radical mediation of activated leukocyte depression of cardiac sarcoplasmic reticulum. Participation of the cyclooxygenase pathway. Circ Res 1983; 53: 584-591

18 Lin MJ, Leung GP, Zhang WM et al. Chronic hypoxia-induced upregulation of store-operated and receptor-operated $\mathrm{Ca} 2+$ channels in pulmonary arterial smooth muscle cells: a novel mechanism of hypoxic pulmonary hypertension. Circ Res 2004; 95: 496-505

19 Kawakami M, Okabe E. Superoxide anion radical-triggered Ca2+ release from cardiac sarcoplasmic reticulum through ryanodine receptor Ca2 + channel. Mol Pharmacol 1998; 53: 497-503

20 Zhou SS, Yang J, Li YQ et al. Effect of Cl- channel blockers on aconitineinduced arrhythmias in rat heart. Exp Physiol 2005; 90: 865-872

21 Faber GM, Silva J, Livshitz $L$ et al. Kinetic properties of the cardiac L-type Ca2 + channel and its role in myocyte electrophysiology: a theoretical investigation. Biophys J 2007; 92: 1522-1543

22 Chen W, Wasserstrom JA, Shiferaw Y. Role of coupled gating between cardiac ryanodine receptors in the genesis of triggered arrhythmias. Am J Physiol Heart Circ Physiol 2009; 297: H171-H180

23 Triggle DJ. Calcium channel antagonists: clinical uses - past, present and future. Biochem Pharmacol 2007; 74: 1-9

24 Niwa N, Nerbonne JM. Molecular determinants of cardiac transient outward potassium current (I(to)) expression and regulation. J Mol Cell Cardiol 2010; 48: 12-25

25 Monsuez IJ. Cardiac potassium currents and channels. Part II: Implications for clinical practice and therapy. Int J Cardiol 1997; 62: 1-12

26 Di Diego JM, Antzelevitch C. High [Ca2 + ]o-induced electrical heterogeneity and extrasystolic activity in isolated canine ventricular epicardium. Phase 2 reentry. Circulation 1994; 89: 1839-1850

27 Yao JA, Jiang M, Fan JS et al. Heterogeneous changes in K currents in rat ventricles three days after myocardial infarction. Cardiovasc Res 1999; 44: 132-145

28 Roden DM, Balser JR, George AL Jr et al. Cardiac ion channels. Annu Rev Physiol 2002; 64: 431-475 